\title{
UKURAN PERUSAHAAN DAN PROFITABILITAS SEBAGAI DETERMINAN NILAI PERUSAHAAN MANUFAKTUR DENGAN STRUKTUR MODAL SEBAGAI VARIABEL MEDIASI
}

\author{
I Made Purba Astakoni* 1), I Wayan Wardita ${ }^{2)}$, Ni Putu Nursiani ${ }^{3)}$ \\ ${ }^{1), 2)}$ Program Studi Manajemen Sekolah Tinggi Ilmu Manajemen Handayani Denpasar \\ ${ }^{3)}$ Program Studi Manajemen Fakultas Ekonomi dan Bisnis Univ Nusa Cendana,NTT \\ *astakonimade@gmail.com
}

\begin{abstract}
This research has several objectives namely; 1) to find out and analyze the effect of company size (size) on company value; 2) to find out and analyze the effect of company size on capital structure; 3) to know and analyze the effect of profitability on capital structure; 4) to find out and analyze the effect of profitability on company value; 5) to find out and analyze the effect of capital structure on firm value; 6) to determine and analyze the role of capital structure in mediating the relationship of company size with firm value; 7) to know and analyze the role of capital structure in mediating the relationship of profitability with firm value. The population in this study are cosmetics and household use manufacturing companies listed on the Indonesia Stock Exchange (BEI) for the period 2011-2018. Sampling was done purposively with predetermined criteria. The data analysis of this study uses the Partial Least Square (PLS) approach. The calculation results show that the first hypothesis; which states that there is a significant positive effect between company size on firm value is not acceptable. The second hypothesis which states the size of the company (size) has a significant positive effect on capital structure is not acceptable. The third hypothesis which states profitability (profitability) has a significant negative effect on capital structure is not acceptable The fourth hypothesis which states that there is a significant positive effect between profitability on firm value can be accepted. The fifth hypothesis which states that there is a significant positive influence between capital structure on firm value cannot be accepted. Based on calculations, the capital structure variable has not been able to be a mediating variable in intervening the influence of company size on firm value. While on the other hand the capital structure variable is able to mediate in intervening the effect of profitability on firm value.
\end{abstract}

Keywords: Firm Size, Profitability, Capital Structure, Firm Value, Panel Data

Abstrak

Penelitian ini memiliki beberapa tujuan yaitu; 1) untuk mengetahui dan menganalisis pengaruh ukuran perusahaan (size) terhadap nilai perusahaan ; 2) untuk mengetahui dan menganalisis pengaruh ukuran perusahaan terhadap struktur modal;3) untuk mengetahui dan menganalisis pengaruh profitabilitas terhadap struktur modal; 4) untuk mengetahui dan menganalisis pengaruh profitabilitas terhadap nilai perusahaan; 5) untuk mengetahui dan menganalisis pengaruh struktur modal terhadap nilai perusahaan; 6) untuk mengetahui dan menganalisis peran struktur modal dalam memediasi hubungan ukuran perusahaan dengan nilai perusahaan;7) untuk mengetahui dan menganalisis peran struktur modal dalam memediasi hubungan profitabilitas dengan nilai perusahaan. Populasi dalam studi ini adalah perusahaan manufaktur sektor kosmetik dan keperluan rumah tangga yang terdaftar di Bursa Efek Indonesia (BEI) periode 2011-2018. Pengambilan sampel dilakukan secara purposive dengan kriteria yang telah ditetapkan sebelumnya. Analisis data studi ini menggunakan pendekatan Partial Least Square (PLS). Hasil perhitungan menunjukkan bahwa hipotesis pertama; yang menyatakan bahwa terdapat pengaruh signifikan positif antara ukuran perusahaan terhadap nilai perusahaan tidak dapat diterima. Hipotesis kedua yang menyatakan ukuran perusahaan (size) berpengaruh positif signifikan terhadap struktur modal tidak dapat diterima. Hipotesis ketiga yang menyatakan profitabilitas (profitability) berpengaruh $\mathrm{n}$ e g a t i f signifikan terhadap struktur modal tidak dapat diterima Hipotesis $\mathrm{k}$ e e $\mathrm{m} \mathrm{p}$ a $\mathrm{t}$ yang menyatakan bahwa terdapat pengaruh signifikan positif antara profitabilitas terhadap nilai perusahaan dapat diterima. Hipotesis k e li ma yang menyatakan bahwa terdapat pengaruh signifikan positif antara struktur modal terhadap nilai perusahaan tidak dapat diterima. Berdasarkan perhitungan, variable struktur modal belum mampu menjadi variable mediasi dalam mengintervensi pengaruh ukuran perusahaan terhadap nilai perusahaan.Sedangkan pada sisi lain variable struktur modal mampu menjadi mediasi dalam mengintervensi pengaruh profitabilitas terhadap nilai perusahaan.

Kata Kunci : Ukuran Perusahaan,Profitabilitas,Struktur Modal,Nilai Perusahaan,Data Panel 


\section{PENDAHULUAN}

Dari sisi investor informasi tentang nilai perusahaan penting untuk pengambilan keputusan investasi saham, sebab hal ini akan membantu investor mengetahui saham mana yang bertumbuh dan memiliki kinerja yang baik (Brigham dan Houston,2011),(Puspitaningtyas 2017) . Pengukuran nilai perusahaan memberikan informasi berkaitan dengan ketertarikan investor untuk berinvestasi dalam saham perusahaan. Pengukuran ini mencerminkan bagaimana saham perusahaan dinilai oleh investor. Semakin tinggi nilai perusahaan mengindikasikan perusahaan tersebut dinilai memiliki kinerja yang baik. Terdapat banyak faktor yang mempengaruhi nilai perusahaan seperti yang diangkat oleh beberapa peneliti diantaranya Ananta, Suardikha, dan Ratnadi (2014) dalam risetnya di BEI mengangkat kepemilikan manajerial,keputusan investasi,keputusan pendanaan dan kebijakan dividen sebagai variabel eksogen dengan nilai perusahaan sebagai variabel endogen. Kemudian Antoro \& Hermningsih (2017) melakukan penelitian di BEI menjabarkan ada beberapa faktor seperti; kebijakan dividen, struktur modal, pertumbuhan perusahaan, profitabilitas, likuiditas, ukuran perusahaan sebagai penentu nilai perusahaan. Rahmawati (2015) di BEI menyatakan bahwa faktor-faktor yang dapat mempengaruhi nilai perusahaan, adalah kepemilikan institusional, kepemilikan manajerial, kebijakan dividen, kebijakan hutang, profitabilitas. Kemudian Moeljadi (2014), Martini et al. (2014) dalam risetnya pada sektor publik di BEI mengangkat variabel independen Corporate Social Responsibility, Corporate Governance dan Company Size dengan variabel dependen value company. Sabrina, Witjaksono, dan Lusianah (2018) di BEI mengangkat variabel indenpenden Invesment Decision,Financial Decision,Dividen Policy sebagai faktor penentu nilai perusahaan.Penelitian (Mindra dan Erawati 2014) di BEI mengangkat variabel eksogen EPS ,ukuran perusahaan,profitabilitas dan leverage dengan variabel endogen nilai perusahaan. Studi yang dilakukan oleh Kurniawati (2016) mengangkat board size, leverage dan kualitas audit sebagai variabel bebas dengan nilai perusahaan sebagai variabel terikat.Adiputra (2016) mengangkat faktor internal dan eksternal yang mempengaruhi nilai perusahaan pada bursa efek negara-negara Asia Tenggara. Faktor internal diidentifikasi dengan ;firm size,financial risk,debt equity ratio,dividen policy, sedangkan faktor eksternal terdiri dari ; interest rate,exchange rate, inflation and economic growth. Penelitian Ayako dan Wamalwa (2015) di Nairobi mengangkat variabel penentu nilai perusahaan (value of firm) dalam bentuk; assets of firm,capital structure, cah flows, dividen ratio, intangible assets, market capitalization, external environment, dan strategic plan. Riset Ibrahim (2017) di Negeria mengangkat leverage, tangibility of assets, size, growth, profitability, earning volatility,ages, liquidity sebagai faktor penentu nilai perusahaan . Awan, Lodhi, dan Hussain (2018) di Pakistan mengangkat variabbel leverage, earnings per share, return on assets, net working capital dan firm size sebagai independent variables serta harga saham sebagai variabel dependent. Studi kali ini dilakukan pada perusahaan manufaktur Sektor Kosmetik dan Keperluan Rumah Tangga yang terdaftar di Bursa Efek Indonesia (BEI) dengan mengangkat kembali variabel ukuran perusahaan,profitabilitas sebagai faktor penentu nilai perusahaan melalui struktur modal sebagai pemediasi dengan menggunakan pendekatan data panel.

Nilai perusahaan dapat memberikan kemakmuran pemegang saham secara maksimum apabila harga saham perusahaan meningkat. Nilai perusahaan menjadi sinyal positif bagi investor, bahwa nilai perusahaan yang tinggi mencerminkan kemakmuran pemegangan saham juga tinggi. Semakin tinggi harga saham, maka makin tinggi kemakmuran pemegang saham (Keown, Maritin, dan David 2010); (Sitepu dan Wibisono 2013). Sesuai riset sebelumnya variabel yang dapat mempengaruhi nilai perusahaan adalah ukuran perusahaan. Ukuran perusahaan yang besar memudahkan suatu perusahaan dalam mendapatkan pendanaan. Kemudahaan ini bisa ditangkap sebagai informasi yang baik karena hal tersebut mengindikasikan bahwa perusahaan mampu mengendalikan kegiatan operasinya dengan baik sehingga akan meningkatkan nilai perusahaan. Selain itu, ukuran perusahaan yang besar dan tumbuh dapat mencerminkan bahwa tingkat profit dimasa mendatang akan semakin baik (Vaeza dan Hapsari 2015). Temuan terdahulu yang telah menguji konsep ini antara lain Novari dan Lestari (2016), Pratama dan Wiksuana (2016) yang mendapatkan ukuran perusahaan berpengaruh signifikan positif terhadap nilai perusahaan.Temuan Wahyudi, Chuzaimah, dan 
Sugiarti (2017) mendapatkan ukuran perusahaan berpengaruh tidak signifikan positif terhadap nilai perusahaan.Bahkan hasil riset Nurminda (2017). menyatakan ukuran perusahaan tidak berpengaruh terhadap nilai perusahaan. Sementara Prastuti dan Sudiartha (2016) menemukan bahwa ukuran perusahaan berpengaruh signifikan negatif terhadap nilai perusahaan. Selain ukuran perusahaan, maka tingkat profitabilitas menjadi penting bagi upaya pencapaian tujuan prusahaan. Suatu perusahaan harus berada dalam kondisi yang menguntungkan (profitable), sebab tanpa keuntungan (profit), maka akan sulit bagi perusahaan menarik minat investor untuk menginvestasikan dananya dalam saham perusahaan. Oleh karenanya, upaya peningkatan profitabilitas penting artinya bagi kelangsungan dan masa depan perusahaan. Hasil riset terdahulu Dj, Artini, dan Suarjaya (2012) , Putra dan Wiagustini (2013) , Lubis, Sinaga, dan Sasongko (2017) , Antoro dan Hermningsih (2017) Puspitaningtyas (2017) yang membuktikan bahwa profitabilitas berpengaruh signifikan positif terhadap nilai perusahaan.Berbeda dengan hasil yang didapat Apriada dan Suardikha (2016) ,Wahyudi, Chuzaimah, dan Sugiarti (2017) dimana signifikan terhadap nilai perusahaan.

Struktur modal yang baik dan optimal adalah struktur modal yang dapat meminimumkan biaya dan menyeimbangkan risiko dengan tingkat pengembalian. Hal ini didukung oleh pendapat (Husnan dan Pudjiastuti 2010), yang menyatakan bahwa "struktur modal yang dapat memaksimumkan nilai perusahaan atau harga saham adalah struktur modal yang terbaik". Struktur modal erat kaitannya dengan harga saham, ini dikarenakan salah satu unsur yang membentuk harga saham adalah persepsi investor atas kinerja perusahaan, dan struktur modal adalah salah satu unsur yang menentukan baik buruknya kinerja perusahaan. Penelitian yang dilakukan oleh Hasibuan, AR, \& Endang NP (2016), Rudangga dan Sudiarta (2013) membuktikan bahwa struktur modal berpengaruh positif signifikan terhadap nilai perusahaan. Namun bertentangan dengan penelitian yang dilakukan Ogolmagai (2011) ,Antoro dan Hermningsih (2017) yang menyatakan bahwa ratio hutang yang diukur dengan DAR dan DER berpengaruh tidak signifikan terhadap nilai perusahaan (Tobin's Q). Hasil penelitian Pratiwi dan Mertha (2017), profitabilitas memiliki pengaruh positif tidak

mendapatkan bahwa kebijakan hutang berpengaruh positif signifikan pada nilai perusahaan.

Berdasarkan kajian empiris sebelumnya, ternyata masing-masing dari faktor penentu tersebut memiliki hubungan dan pengaruh yang masih beragam terhadap nilai perusahaan. Studi ini merupakan kelanjutan dari riset riset sebelumnya dan mengangkat konsep beberapa konsep berbeda. Beberapa perbedaan yang ada bisa dilihat dari sisi waktu/periode data, populasi dan sampel penelitian, variable dan proksinya, model data panel seimbang serta alat analisis yang digunakan termasuk model mediasi dengan pendekatan uji sobel.Atas uraian tersebut diatas, maka tujuan dari studi ini adalah 1) untuk mengetahui dan menganalisis pengaruh ukuran perusahaan (size) terhadap nilai perusahaan, 2) untuk mengetahui dan menganalisis pengaruh ukuran perusahaan terhadap struktur modal perusahaan, 3) untuk mengetahui dan menganalisis pengaruh profitabilitas terhadap struktur modal; 4) untuk mengetahui dan menganalisis pengaruh profitabilitas terhadap nilai perusahaan; 5) untuk mengetahui dan menganalisis pengaruh struktur modal terhadap nilai perusahaan; 6) untuk mengetahui dan menganalisis peran struktur modal dalam memediasi hubungan ukuran perusahaan dengan nilai perusahaan;7) untuk mengetahui dan menganalisis peran struktur modal dalam memediasi hubungan profitabilitas dengan nilai perusahaan.

\section{TINJAUAN PUSTAKA Nilai Perusahaan}

Sejalan dengan yang diungkapkan oleh Siallagan dan Machffoedz (2006) bahwa tujuan utama perusahaan adalah memaksimalkan nilai perusahaan. Moeljadi (2014) menyatakan beberapa konsep nilai untuk menggambarkan nilai perusahaan, antara lain: nilai nominal, nilai pasar, nilai intrinsik, nilai buku, dan nilai likuidasi. Lebih lanjut dijelaskan bahwa konsep yang paling representatif untuk menentukan kinerja pasar perusahaan adalah nilai intrinsik, tetapi sangat sulit untuk memperkirakan nilai intrinsik, karena penentuannya memerlukan kemampuan untuk mengidentifikasi variabel signifikan yang menentukan profitabilitas perusahaan.Variabelvariabel itu berbeda dari satu perusahaan ke perusahaan yang lain. Oleh karena itu, nilai pasar digunakan dengan alasan kemudahan data juga didasarkan pada nenilaian yang moderat Nilai

Jurnal KRISNA: Kumpulan Riset Akuntansi Volume 11, Nomor 22020 CC-BY-SA 4.0 License

Page 37 
perusahaan dalam studi ini didefinisikan sebagai nilai pasar dari saham perusahaan. Nilai pasar merupakan nilai dari saham yang berlaku dipasaran. Nilai ini ditentukan oleh kekuatan penawaran dan permintaan pasar atas saham perusahaan. Nilai perusahaan dapat memberikan kemakmuran pemegang saham secara maksimum apabila harga saham perusahaan meningkat. Nilai perusahaan menjadi sinyal positif bagi investor, bahwa nilai perusahaan yang tinggi mencerminkan kemakmuran pemegangan saham juga tinggi. Dalam beberapa riset nilai perusahaan lazim didekati dengan beberapa proksi seperti ; price to book value (PBV), dan rasio tobin's $Q$ (Puspitaningtyas 2017),(I. M. P. Astakoni dan Wardita 2020)

\section{Ukuran Perusahaan}

Ukuran peusahaan (size) merupakan suatu indikator yang menunjukkan kekuatan finansial perusahaan. Ukuran perusahaan dianggap mampu mempengaruhi nilai perusahaan,karena semakin besar ukuran atau skala perusahaan maka akan semakin mudah pula perusahaan memperoleh sumber pendanaan baik yang bersifat internal maupun eksternal. Ukuran perusahaan yang besar mencerminkan bahwa perusahaan tersebut sedang mengalami perkembangan dan pertumbuhan yang baik sehingga meningkatkan nilai dari suatu perusahaan. Nilai perusahaan yang meningkat dapat ditandai dengan total aktiva perusahaan yang mengalami kenaikan yang lebih besar dibandingkan dengan jumlah hutang perusahaan(Pratama dan Wiksuana 2016) .Menurut Seftianne dan Ratih (2011), menyatakan bahwa penentuan besar kecilnya skala perusahaan dapat ditentukan berdasarkan total penjualan, total aktiva, rata-rata tingkat penjualan dan rata-rata total aktiva. Dalam studi kali ini untuk melihat ukuran perusahaan (Size) dipergunakan pendekatan total aset (Ln Total Aktiva) (I.M.P Astakoni dan Nursiani 2019)

\section{Profitabilitas}

Profitabilitas (profitability) adalah kemampuan perusahaan memperoleh laba melalui operasional usahanya dengan menggunakan dana aset yang dimiliki oleh perusahaan. Pengertian lain juga menyebutkan bahwa profitabilitas (profitability) menunjukkan kemampuan perusahaan untuk menghasilkan keuntungan dan mengukur tingkat efisiensi operasional dan efisiensi dalam menggunakan harta yang dimilikinya.Profitabilitas adalah hasil akhir dari sejumlah kebijakan dan keputusan yang dilakukan oleh perusahaan (Brigham \& Houston 2011). Ada beberapa ukuran yang digunakan untuk melihat kondisi profitabilitas suatu perusahaan, antara lain Return On Asset. Semakin tinggi perbandingan laba bersih terhadap total aktiva maka akan semakin baik bagi perusahaan (Syamsuddin 2004) .Menurut Brigham dan Houston (2011) (Brigham, EF. 2006)ukuran yang bisa mewakili profitabilitas adalah Return on Asset (ROA), Return on Equity (ROE), Operating Profit Margin (OPM) on Sales dan Basic Earning Power (BEP). Sedangkan menurut Horne dan John M (2012) , profitabilitas adalah kemampuan perusahaan untuk menghasilkan laba pada periode tertentu yang bisa diukur dengan menggunakan return on aset, return on equity, dan net profit margin. Dalam studi kali ini profitabilitas akan diproksi dengan menggunakan pendekatan return on equity (ROE) (I. M. P. Astakoni dan Utami 2019)

\section{Struktur Modal}

Struktur modal adalah perimbangan atau perbandingan antara jumlah hutang jangka panjang dengan modal sendiri (Riyanto, 2010). Pendapat lain mengatakan bahwa struktur modal merupakan perimbangan jumlah hutang jangka pendek yang bersifat permanen, hutang jangka panjang, saham preferen, dan saham biasa (Sartono 2010) Berdasarkan beberapa pendapat tersebut, pada dasarnya struktur modal yaitu pembiayaan perusahaan yang bersifat permanen yang terdiri dari hutang jangka panjang, saham biasa dan saham preferen . Brigham dan Houston (2011) mengatakan struktur modal yang optimal dapat didefinisikan sebagai "struktur yang akan memaksimalkan harga saham perusahaan tersebut". Struktur modal yang baik dan optimal adalah struktur modal yang dapat meminimumkan biaya dan menyeimbangkan risiko dengan tingkat pengembalian. Hal ini didukung oleh pendapat (Husnan dan Pudjiastuti 2010), yang menyatakan bahwa "struktur modal yang dapat memaksimumkan nilai perusahaan atau harga saham adalah struktur modal yang terbaik". 
Struktur modal erat kaitannya dengan harga saham, ini dikarenakan salah satu unsur yang membentuk harga saham adalah persepsi investor atas kinerja perusahaan, dan struktur modal adalah salah satu unsur yang menentukan baik buruknya kinerja perusahaan.Faktor-faktor yang mempunyai pengaruh terhadap strukur modal perusahaan yaitu (1) Stabilitas penjualan, (2) Struktur Aset, (3) Leverage Operasi, (4) Tingkat Pertumbuhan, (5)Profitabilitas, (6) Pajak, (7) Sikap Manajemen, (8)Pengendalian, (9) Kondisi Pasar, (10) Sikap pemberi pinjaman dan agen pemberi peringkat, (11) Kondisi internal perusahaan, (12) Fleksibilitas keuangan (Brigham dan Houston, 2006). Kusuma \& Arifin, (2012) , Mas'ud, (2008) menyatakan bahwa variabel-variabel yang mempengaruhi struktur modal adalah: (1) tingkat pertumbuhan penjualan (sales growth); (2) debt ratio; (3) profitability; (4) besarnya suatu perusahaan (firm size); (5) struktur aktiva (asset structure); (6) cost of financial distress. Struktur modal dipengaruhi oleh bermacam-macam faktor baik dari luar perusahaan maupun di dalam perusahaan. Faktor eksternal perusahaan meliputi kondisi pasar modal, tingkat bunga, dan stabilitas politik sedangkan faktor internal seperti profitabilitas perusahaan, ukuran perusahaan dan stabilitas dividen. Struktur modal dapat diukur dengan Debt Ratio (DR) dan Debt to Equity Ratio (DER). DR merupakan ratio pengukuran yang menunjukkan seberapa besar total aset yang dimiliki perusahaan dalam pendanaannya berasal dari hutang. DER merupakan ratio pengukuran yang menunjukkan perbandingan total hutang dengan equitas perusahaan (Murhadi 2013). Sedangkan menurut Horne dan John M (2012) alat ukur yang bisa digunakan untuk melihat besarnya struktur modal adalah debt to aset ratio (DAR) dan debt to equity ratio (DER). Dalam studi kali ini struktur modal akan diproksi dengan menggunakan pendekatan debt to equity ratio (DER) (I. M. P. Astakoni dan Utami 2019)

\section{Pengaruh ukuran perusahaan terhadap nilai perusahaan}

Jumlah asset yang besar akan menurunkan nilai perusahaan jika dinilai dari sisi pemilik perusahaan. Akan tetapi jika dilihat dari sisi manajemen, kemudahan yang dimilikinya dalam mengendalikan perusahaan akan meningkatkan nilai perusahaan (Analisa 2011). Dua sudut pandang yang saling bertentangan tentang hubungan ukuran perusahaan (size) dengan nilai perusahaan (Firm Value), pertama, perusahaan besar tidak menganggap biaya kebangkrutan langsung sebagai variabel aktif dalam menentukan tingkat leverage karena biaya ini ditetapkan oleh konstitusi dan merupakan proporsi yang lebih kecil dari total nilai perusahaan. Juga, perusahaan besar yang lebih terdiversifikasi memiliki peluang kebangkrutan yang lebih kecil (Titman 1984) . Jadi, orang mungkin mengharapkan hubungan positif antara ukuran dan nilai suatu perusahaan. Kedua, bertentangan dengan pandangan pertama, Rajan dan Zingales (1995) berpendapat bahwa ada informasi asimetris yang kurang tentang perusahaan yang lebih besar. Ini mendorong perusahaan besar untuk menggunakan pendanaan ekuitas. Berarti ada hubungan negatif antara ukuran perusahaan dan nilai suatu perusahaan. Mengikuti studi Titman (1984) dan juga temuan dari Martini et al. (2014), menyatakan terdapat pengaruh signifikan positif ukuran perusahaan pada perusahaan manufaktur di BEI periode 20092011. Juga sejalan dengan hasil yang didapat Pratama dan Wiksuana (2016), maka dalam studi kali ini mengharapkan hubungan yang positif antara ukuran perusahaan dan nilai perusahaan dari perusahaan manufaktur sektor kosmetik dan Keperluan RT yang terdaftar di BEI. sehingga hipotesis yang diangkat. H1: Ukuran perusahaan (Size) berpengaruh signifikan positif terhadap nilai perusahaan

\section{Pengaruh ukuran perusahaan terhadap struktur modal}

Ukuran perusahaan (Firm Size) merupakan salah satu faktor yang dipertimbangkan perusahaan dalam menentukan berapa besar kebijakan keputusan pendanaan (struktur modal) dalam memenuhi ukuran atau besarnya asset perusahaan. Moeldjadi, (2006) berpendapat bahwa "suatu perusahaan yang berukuran besar lebih mudah memperoleh pinjaman jika dibandingkan dengan perusahaan kecil", akan tetapi, perusahaan besar seringkali mampu membiayai kegiatan operasional mereka sendiri dengan sumber internal daripada sumber eksternal, hal ini dikarenakan perusahaan besar memiliki pendapatan yang besar dibandingkan dengan perusahaan kecil, sehingga tidak perlu bergantung pada sumber pendanaan eksternal. Besar kecilnya perusahaan sangat tergantung pada struktur modal, terutama berkaitan dengan kemampuan memperoleh pinjaman. 
Perusahaan besar lebih mudah memperoleh pinjaman, sehingga mereka akan cenderung untuk berhutang karena kemungkinan mengalami risiko kebangkrutan yang rendah, disamping itu perusahaan yang besar dimana sahamnya tersebar sangat luas akan lebih berani mengeluarkan saham baru dalam memenuhi kebutuhannya untuk membiayai pertumbuhan penjualan dibandingkan dengan perusahaan yang kecil" (Riyanto 2010) .Menurut Seftianne and Ratih (2011), menyatakan bahwa perusahaan yang besar juga memiliki kecenderungan untuk menggunakan sumber pendanaan eksternal dari pada perusahaan kecil karena accessibility perusahaan ke pasar modal. Oleh karena itu, dapat disimpulkan semakin besar ukuran perusahaan maka struktur modal akan semakin tinggi. Konsep ini sejalan dengan temuan (Hermuningsih (2012), Septiono et al. (2013) yang menyatakan pengaruh ukuran perusahaan terhadap struktur modal positif signifikan,sehingga hipotesis yang diangkat adalah; H2 : Ukuran perusahaan (Firm Size) berpengaruh signifikan positif terhadap struktur modal.

\section{Pengaruh profitabilitas terhadap struktur} modal

Profitabilitas adalah kemampuan perusahaan memperoleh laba dalam hubungannya dengan penjualan, total aktiva maupun modal sendiri (Sartono, 2010). Mai, (2006) menjelaskan profitabilitas merupakan kemampuan peruahaan untuk memperoleh laba. Keputusan pendanaan yang dilakukan secara tidak cermat akan menimbulkan biaya tetap dalam bentuk biaya modal yang tinggi, yang selanjutnya dapat berakibat pada rendahnya profitabilitas perusahaan (Kartini and Tulus 2008) . Jadi dengan kata lain, keputusan pendanaan atau struktur modal sangat berpengaruh terhadap rendah atau tingginya profitabilitas suatu perusahaan. Menurut pecking order theory, perusahaan dengan tingkat keuntungan yang besar memiliki sumber pendanaan internal yang lebih besar dan memiliki kebutuhan untuk melakukan pembiayaan investasi melalui pendanaan eksternal yang lebih kecil (Schoubben, F. and Van Hulle 2004), (Adrianto and Wibowo 2007) . Jadi dengan demikian, teori ini memprediksikan profitabilitas berpengaruh negatif terhadap struktur modal. Hasil yang didapat (Agha 2015), (Chen and Chen 2011) . (Kusuma and Arifin 2012) .(Elim and Yusfarita 2010), profitabilitas (profitability) berpengaruh negatif signifikan terhadap semua rasio hutang. Kajian empiris Septiono et al., (2013) profitabilitas berpengaruh negatif dan signifikan terhadap ratio hutang pada perusahaan Non-Bank yang terdaftar di BEI periode 2009-2011.Berdasarkan pernyataan tersebut, maka dapat dirumuskan hipotesis sebagai berikut. H3: Profitabilitas berpengaruh signifikan negatif terhadap struktur modal.

\section{Pengaruh profitabilitas terhadap nilai perusahaan}

Tingkat profitabilitas menjadi penting bagi upaya pencapaian tujuan prusahaan. Suatu perusahaan harus berada dalam kondisi yang menguntungkan (profitable), sebab tanpa keuntungan (profit), maka akan sulit bagi perusahaan menarik minat investor untuk menginvestasikan dananya dalam saham perusahaan. Oleh karenanya, upaya peningkatan profitabilitas penting artinya bagi kelangsungan dan masa depan perusahaan.Kemampuan suatu perusahaan untuk menghasilkan laba atau keuntungan dalam suatu periode mencerminkan kemampuan perusahaan meningkatkan nilai perusahaan yang tercermin pada harga saham. Tingkat profitabilitas menjadi sinyal positif bagi investor dalam memprediksi nilai perusahaan. Studi ini memprediksikan bahwa profitabilitas berpengaruh signifikan positif terhadap nilai perusahaan. Prediksi ini merujuk pada hasil riset terdahulu oleh Dj, Artini, dan Suarjaya (2012) , Putra dan Wiagustini (2013) , Lubis, Sinaga, dan Sasongko (2017) , Antoro dan Hermningsih (2017) (Puspitaningtyas 2017) yang membuktikan bahwa profitabilitas berpengaruh signifikan positif terhadap nilai perusahaan . Berdasarkan konsep dan temuan terdahulu maka ; H4: Profitabilitas berpengaruh signifikan positif terhadap nilai perusahaan

Pengaruh struktur modal terhadap nilai perusahaan

Menurut konsep pecking order theory perusahaan dengan tingkat keuntungan yang besar akan lebih banyak menggunakan dana internal terlebih dahulu sebelum menggunakan hutang. Struktur modal merupakan kemampuan perusahaan memperoleh pinjaman melalui pasar modal. Struktur modal adalah perimbangan antara modal asing dengan modal sendiri (Husnan dan Pudjiastuti 2010). Jadi dengan kata lain struktur modal merupakan proporsi kebutuhan belanja 
perusahaan dengan sumber pendanaan jangka panjang yang berasal dari dana eksternal. Apabila dengan adanya pendanaan tersebut dapat dimanfaatkan dengan baik oleh perusahaan sehingga dapat menghasilkan laba yang relatif tinggi maka penggunaan hutang akan meningkatkan nilai perusahaan Akan tetapi apabila penggunaan hutang tersebut justru akan menimbulkan beban perusahaan yang relatif tinggi sebagai dampak perusahaan tidak mampu mengelola dengan baik maka hal ini akan mengakibatkan turunnya nilai perusahaan. Beberapa kajian empiris seperti Hermuningsih (2012) , Anjarwati, Chabachib, dan Demi (2015) mendapatkan struktur modal berpengaruh positif signifikan terhadap nilai perusahaan pada perusahaan manufaktur yang terdaftar di BEI. Fajar, Hasan, dan Gusnardi (2018) mendapatkan kebijakan hutang berpengaruh positif signifikan terhadap nilai perusahaan pada Subsektor Perkebunan Yang Terdaftar Di Bursa Efek Indonesia Tahun 2012-2016. Berdasarkan uraian tersebut dapat dirumuskan hipotesis sebagai berikut: H5: Struktur Modal berpengaruh signifikan positif terhadap Nilai Perusahaan

\section{METODE PENELITIAN}

\section{Populasi dan Sampel}

Populasi dalam studi ini adalah perusahaan manufaktur sektor kosmetik dan keperluan rumah tangga yang terdaftar di Bursa Efek Indonesia (BEI) periode 2011-2018. Pengambilan sampel dilakukan secara purposive dengan kriteria yang telah ditetapkan sebelumnya yaitu; (1) Perusahaan manufaktur sektor kosmetik dan keperluan rumah tangga yang terdaftar di BEI periode 2011-2018, (2) Perusahaan manufaktur sektor kosmetik dan keperluan rumah tangga yang melaporkan laporan keuangan yang berakhir per 31 Desember 20112018. Berdasarkan kriteria yang ditetapkan maka studi ini didasarkan pada data panel dengan melibatkan sebanyak 4 perusahaan sektor kosmetik dan keperluan rumah tangga yang terdaftar di BEI periode 2011-2018 sebagai berikut:

Tabel 1

Sampel Penelitian

\begin{tabular}{|c|c|c|}
\hline No & Nama Perusahaan & Kode Saham \\
\hline 1 & PT Mandom Indonesia & TCID \\
& Tbk & \\
2 & PT Unilever Indonesia & UNVR \\
& Tbk & \\
3 & PT. Mustka Ratu Tbk & MRAT \\
4 & PT Martina Berto Tbk & MBTO \\
\hline
\end{tabular}

Jadi jumlah sampel penelitian sebanyak 4 perushaan masing-masing diambil selama 8 tahun laporan keuangan sehingga didapat jumlah observasi penelitian sebanyak 4 × $8=32$ observasi. Definisi Operasional dan Pengukuran Variabel Variabel yang digunakan dalam penelitian ini adalah variabel endogen dan variabel eksogen.Variabel endogen (endogenous variable) merupakan variabel yang dipengaruhi atau yang menjadi akibat, karena adanya variabel eksogen.Variabel eksogen merupakan variabel yang mempengaruhi atau yang menjadi sebab perubahannya atau timbulnya variabel endogen (Sugiyono 2007,54). Variabel endogen dalam penelitian ini adalah nilai perusahaan (Y2). Sedangkan variabel eksogen dalam penelitian ini adalah ukuran perusahaan (X1) dan profitabilitas (X2). Disamping kedua jenis variable tersebut studi ini juga mengangkat satu variable intervening/mediasi yaitu struktur modal (Y1).

Ukuran perusahaan (X1)

Ukuran perusahaan merupakan cerminan total dari aset yang dimiliki suatu perusahan, sehingga ukuran peusahaan (size) merupakan suatu indikator yang menunjukkan kekuatan finansial perusahaan. Ukuran Perusahaan dalam studi ini adalah besar kecilnya perusahaan ini diukur melalui logaritma natural dari total aset (Ln total aset).

Profitabilitas (X2)

Profitabilitas merupakan kemampuan perusahaan memperoleh laba melalui operasional usahanya dengan menggunakan dana aset yang dimiliki oleh perusahaan. Pengukuran profitabilitas dalam penelitian ini diukur menggunakan Return On Equity (ROE) . ROE 
merupakan rasio pengukuran yang menunjukkan seberapa besar pendapatan yang diterima bagi pemegang saham terhadap investasi yang ditanamkan

Struktur modal (Y1)

Struktur modal adalah suatu tingkat kemampuan perusahaan dalam menggunakan aset dan atau dana yang mempunyai beban tetap (hutang dan atau saham istimewa) dalam rangka mewujudkan tujuan perusahaan untuk memaksimisasi kekayaan pemilik perusahaan. Struktur modal dalam penelitian ini diproksi dengan menggunakan indikator tunggal debt to equity ratio (DER) Nilai perusahaan (Y2)
Nilai Perusahaan adalah harga saham yang bersedia dibayar oleh investor untuk setiap lembar saham perusahaan, sehingga dapat dikatakan bahwa nilai perusahaan merupakan persepsi investor terhadap perusahaan yang selalu dikaitkan dengan harga saham. Dalam studi kali ini nilai perusahaan diproksi dengan menggunakan rasio tobin's $Q$ yang didapat dihitung melalui perkalian antara harga saham penutupan kali jumlah saham penutupan, plus Debt kemudian dibagi Total Aset

Berdasarkan definisi operasional dan pengukuran variabel, maka dapat disajikan dalam bentuk tabel 2 berikut;

Tabel 2

Sifat,Jenis dan Pengukuran Variabel

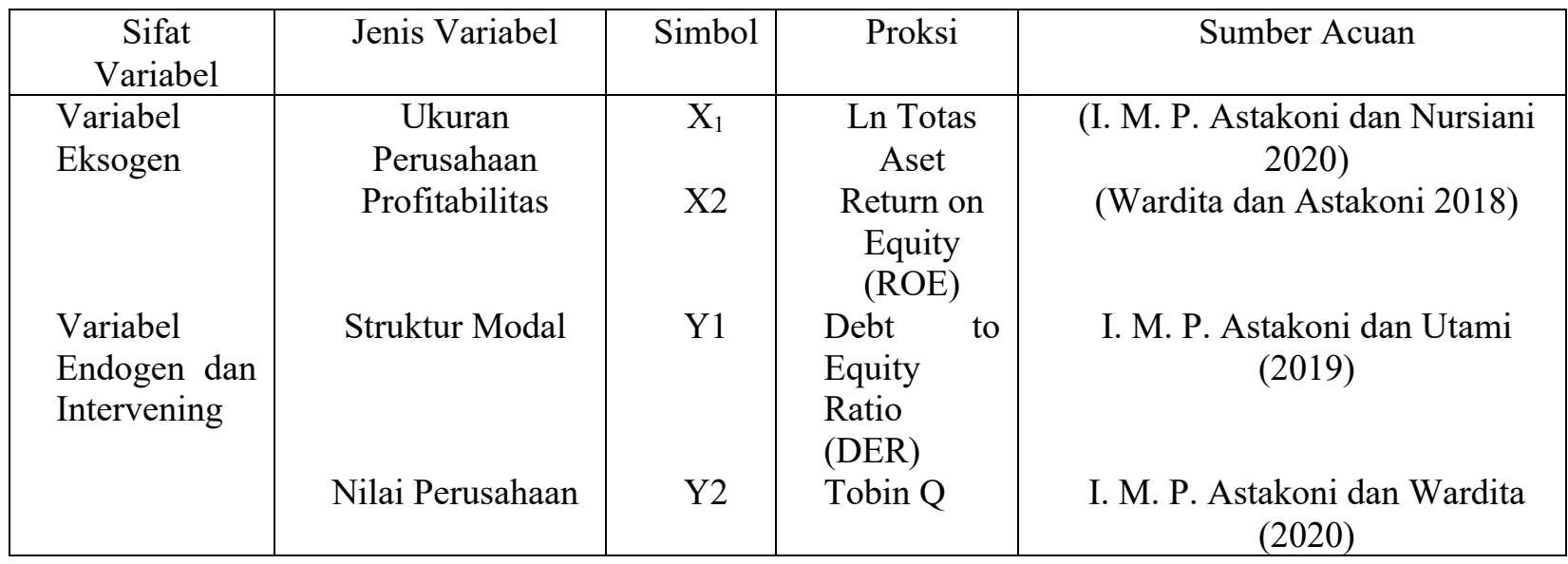

\section{Teknik Analisis Data}

Analisis Statistik Deskriptif

Statistik deskriptif adalah statistik yang digunakan untuk menganalisis data dengan cara mendeskripsikan data yang didapat tanpa bermaksud membuat kesimpulan yang berlaku umum (Sugiyono 2007,25). Pada analisis ini yaitu mendeskripsikan variabel yang terdapat dalam penelitian menggunakan bantuan program spss ver 22 .

Analisis Statistik Inferensial

Pada fenomena bisnis, sebuah variabel endogen dapat dipengaruhi oleh beberapa variabel eksogen, dan variable eksogen yang lain juga mampu mempengaruhi variabel endogen secara sekaligus,sehingga mengakibatkan model penelitian menjadi sangat rumit (Suliyanto 2011,65),(Ferdinand 2014,98) .Dalam penelitian ini analisis data menggunakan pendekatan Partial
Least Square (PLS). PLS adalah model persamaan Structural Equation Modeling (SEM) yang berbasis komponen atau varian. PLS merupakan metode analisis yang powerfull (Ghozali 2011,88) karena tidak didasarkan pada banyak asumsi.Dalam PLS path modeling terdapat dua model yaitu outler model dan inner model.Perlu diketahui untuk analisis regresi berganda dengan variabel obseved dengan pendekatan PLS tidak perlu melakukan pengukuran model (measurement model), sehingga langsung dilakukan estimasi model struktural (Latan dan Ghozali 2012,304),(Budhiasa 2016;36)

Outler Model (Measurement Model)

Terkait dengan indikator-indikator yang membentuk variabel laten dalam penelitian ini bersifat formatif, maka evaluasi model pengukuran (measurement model/outer model), dievaluasi dengan substantive contennya yaitu dengan 
membandingkan besarnya weight dan melihat signifikansi dari ukuran weight tersebut. Signifikansi weight indikator formatif diperoleh melalui prosedur boostrapping (Latan dan Ghozali 2012)

Inner Model (Structural Model).

Evaluasi model struktural (Structural Model/Inner Model) merupakan pengujian terhadap hipotesis penelitian. Apabila diperoleh nilai t-statistik lebih besar dari 1,96 dapat disimpulkan pengaruh antar variabel signifikan demikian sebaliknya.

Uji Sobel

Uji sobel

pada intinya

kekuatan

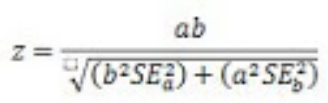

(Sobel Test) menguji pengaruh tidak langsung antara variable eksogen terhadap variable endogen melalui variable pemoderasi.Dalam menguji model mediasi (intervening) dengan uji sobel secara sederhana diformulasikan sebagai berikut :(Ferdinand 2014, 304)
Dimana ; $\mathrm{a}=$ koefisien regresi untuk pengaruh variable eksogen ke variable mediasi; $b=$ koefisien regresi untuk pengaruh variable mediasi ke variable endogen. Sedangkan SEa adalah standar error of estimation dari pengaruh variable eksogen ke variable mediasi; SEb adalah standar error of estimation pengaruh variable mediasi ke variable endogen.

Seperti pengujian pada umumnya, hipotesis diterima bila hasil perhitungan menghasilkan nilai $\mathrm{Z}$ sobel $>1,98$ dengan tingkat signifikan $<5 \%$

\section{HASIL DAN PEMBAHASAN}

Hasil Penelitian

Analisis Statistik Deskriptif

Deskripsi variabel ukuran perusahaan (X1),profitabilitas (X2), struktur modal (Y1) dan Nilai Perusahaan (Y2) Dalam mengidentifikasi deskripsi dari masing-masing variabel tersebut, maka berikut ini disajikan hasil pengolahan data sebagai berikut;

Tabel 3

Statistik Deskriptif Variabel Penelitian

\begin{tabular}{|l|c|c|c|c|c|}
\hline \multicolumn{1}{|c|}{ Variabel Pnelitian } & & & & & \\
\hline Ukuran Perusahaan (X1) & 32 & 26,7695 & 30,6027 & 28,1526 & 1,3809 \\
Profitabilitas (X2) & 32 & $(0,0599)$ & 1,3585 & 0,3585 & 0,5277 \\
Struktur modal (Y1) & 32 & 0,0977 & 1,9084 & 0,4264 & 0,4138 \\
Nilai Perusahaan (Y2) & 32 & 0,4207 & 3,5059 & 1,3634 & 0,8801 \\
Valid N (listwise) & 32 & & & & \\
\hline
\end{tabular}

Sesuai Tabel 3, pada variabel ukuran perusahaan (X1) didapat nilai rata-rata (mean) sebesar 28,1526, stadar deviasi sebesar 1,3809 dengan nilai tertinggi (maximum) sebesar 30,6027 dan nilai terendah (minimum) 26,7695. Pada variabel profitabilitas (X2) didapat nilai rata-rata (mean) sebesar 0,3585 , standar deviasi sebesar 0,5277, dengan nilai tertinggi (maximum) sebesar 1,3585 dan nilai terendah 0,0599. Pada variabel struktur modal (Y1) memiliki rata-rata (mean) sebesar 0,4264, dengan standar deviasi 0,4138 . Nilai tertinggi (maximum) 1,9084 dan nilai terendah (minimum) 0,0977. Pada variabel nilai perusahaan (Y2) didapat nilai rata-rata (mean) sebesar 1,3634, standar viasinya 0,8801 dan dengan nilai tertinggi (maximum) sebesar 3,5059 dan nilai terendah (minimum) 0,4207.
Analisis Statistik Infrensial

Hasil perhitungan ketepatan model memperlihatkan koefisien determinasi yang disesuaikan ( $R$ Square Adjusted) bahwa kontribusi model untuk menjelaskan hubungan struktural dari kelima variabel yang diteliti adalah sebesar 53,80\%) untuk nilai perusahaan atau dengan kata lain, informasi yang terkandung dalam data sebesar $53,80 \%$ dapat dijelaskan oleh model tersebut Jadi sisanya sebesar $46,20 \%$ dijelaskan oleh variabel lain yang tidak diangkat dalam model penelitian ini. Sedangkan koefisien determinasi yang disesuaikan ( $R$ Square Adjusted) dari struktur modal adalah sebesar 27,00\%) atau dengan kata lain, informasi yang terkandung dalam data hanya sebesar $27,00 \%$ dapat dijelaskan oleh 
model tersebut Jadi sisanya sebesar $73,00 \%$ dijelaskan oleh variabel lain yang tidak diangkat dalam model penelitian ini

Dalam studi ini, oleh karena menggunakan pendekatan indikator tunggal dan bersifat formatif maka hanya dilakukan uji inner model. Uji inner model dipergunakan untuk mengevaluasi hubungan antar konstruk laten seperti yang telah dihipotesiskan dalam penelitian ini. Berdasarkan hasil analisis dengan PLS, didapatkan hasil dari
Inner Weight menunjukkan bahwa nilai perusahaan, dipengaruhi oleh ukuran perusahaan (Size), profitabilitas dan struktur modal, yang kesemua ini akan djelaskan pada pengujian hipotesis. Melalui Tabel 4 memberikan gambaran output estimasi untuk pengujian model struktural dimana hasil yang diharapkan adalah Ho ditolak atau nilai sig $<0,05$ (atau t-statistic $>1,96$ )

Tabel 4

Path Analysis dan Pengujian Hipotesis

\begin{tabular}{|l|c|c|r|r|r|c|}
\hline Path Analysis & $\begin{array}{c}\text { Original } \\
\text { Sample } \\
(\mathrm{O})\end{array}$ & $\begin{array}{c}\text { Sample } \\
\text { Mean } \\
(\mathrm{M})\end{array}$ & $\begin{array}{c}\text { Standard } \\
\text { Deviasi } \\
\text { (STDEV) }\end{array}$ & $\begin{array}{c}\text { T Statistics } \\
\text { (O/STERR) }\end{array}$ & $\begin{array}{c}\text { P- } \\
\text { Value }\end{array}$ & Keterangan \\
\hline $\begin{array}{l}\text { Ukuran perusahaan } \\
\rightarrow \text { Nilai } \\
\text { perusahaan }\end{array}$ & $-0,020$ & 0,006 & 0,179 & 0,111 & 0,911 & $\begin{array}{c}\text { Tidak } \\
\text { Signifikan }\end{array}$ \\
\hline $\begin{array}{l}\text { Ukuran perusahaan } \\
\rightarrow \text { Struktur modal }\end{array}$ & $-0,101$ & $-0,073$ & 0,263 & 0,385 & 0,700 & $\begin{array}{c}\text { Tidak } \\
\text { Signifikan }\end{array}$ \\
\hline $\begin{array}{l}\text { Profitabilitas } \rightarrow \\
\text { Struktur modal }\end{array}$ & 0,543 & 0,513 & 0,168 & 3,224 & 0,001 & Signifikan \\
\hline $\begin{array}{l}\text { Profitabilitas } \rightarrow \\
\text { Nilai perusahaan }\end{array}$ & 0,494 & 0,515 & 0,161 & 3,062 & 0,002 & Signifikan \\
\hline $\begin{array}{l}\text { Struktur modal } \rightarrow \\
\text { Nilai perusahaan }\end{array}$ & 0,365 & 0,326 & 0,192 & 1,963 & 0,048 & Signifikan \\
\hline
\end{tabular}

\section{Hasil penelitian dan pembahasan \\ Pengaruh ukuran perusahaan terhadap nilai perusahaan}

Hipotesis pertama; yang menyatakan bahwa terdapat pengaruh signifikan positif antara ukuran perusahaan terhadap nilai perusahaan.Hasil analisis menemukan koefisien sebesar $-0,020$ (negatif) dengan nilai t hitung $0,111(<1,96)$ atau nilai $\mathrm{p}$-value sebesar $0,911(\mathrm{p}>0,05)$. Ini berarti ukuran perusahaan berpengaruh negative tidak signifikan terhadap nilai perusahaan sehingga hipotesis pertama tidak dapat diterima. Hasil studi ini mendukung temuan Naceur dan Goaied (2002) yang mendapatkan ada pengaruh negatif antara ukuran perusahaan terhadap nilai perusahaan. Bahkan hasil riset Nurminda (2017). menyatakan ukuran perusahaan tidak berpengaruh terhadap nilai perusahaan. Sementara hasil studi ini tidak mendukung penelitian Wahyudi, Chuzaimah, dan Sugiarti (2017) mendapatkan ukuran perusahaan berpengaruh tidak signifikan positif terhadap nilai perusahaan.Sementara hasil studi ini tidak sejalan mendapatkan terdapat pengaruh signifikan positif ukuran perusahaan terhadap nilai perusahaan pada perusahaan manufaktur di BEI periode 2009-2011. Juga tidak sejalan dengan hasil riset Pratama and Wiksuana (2016) mendapatkan terdapat pengaruh signifikan positif ukuran perusahaan (Firm Size) terhadap nilai perusahaan (Firm Value) pada perusahaan telekomunikasi yang terdaftar di BEI . Nampaknya sesuai dengan pendapat Rajan dan Zingales (1995) bahwa ada informasi asimetris yang kurang tentang perusahaan yang lebih besar. Ini mendorong perusahaan besar untuk menggunakan pendanaan ekuitas. Jadi itu berarti ada hubungan negatif antara ukuran perusahaan dan nilai suatu perusahaan.

\section{Pengaruh ukuran perusahaan terhadap struktur modal}

Hasil pengujian hipotesis kedua ; diperoleh bahwa ukuran perusahaan (size) berpengaruh positif signifikan terhadap struktur modal. Hasil analisis menemukan koefisien sebesar -0,101 (negatif) dengan nilai $\mathrm{t}$ hitung $0,385(<1,96)$ atau nilai $\mathrm{p}$ -

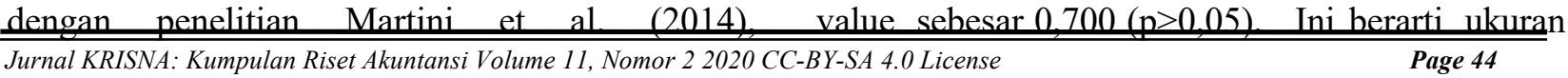


perusahaan berpengaruh negative tidak signifikan terhadap struktur modal sehingga hipotesis kedua tidak dapat diterima.Hasil penelitian ini sejalan dengan kajian yang didapat oleh Kosimpang (2017) bahwa ukuran perusahaan tidak berpengaruh terhadap struktur modal. Sementara hasil penelitian ini tidak mendukung temuan Septiono, Suhadak, and Darminto (2013), Hermuningsih (2012) yang menyatakan pengaruh ukuran perusahaan terhadap struktur modal positif signifikan. Kajian ini tidak sejalan dengan pendapat Riyanto (2010) bahwa perusahaan besar lebih mudah memperoleh pinjaman, sehingga mereka akan cenderung untuk berhutang karena kemungkinan mengalami risiko kebangkrutan yang rendah. Disamping itu perusahaan yang besar dimana sahamnya tersebar sangat luas akan lebih berani mengeluarkan saham baru dalam memenuhi kebutuhannya untuk membiayai pertumbuhan penjualan dibandingkan dengan perusahaan yang kecil.

\section{Pengaruh profitabilitas terhadap struktur modal}

Hasil pengujian hipotesis ketiga; diperoleh bahwa profitabilitas (profitability) berpengaruh positif signifikan terhadap struktur modal . Hal ini ditunjukkan oleh nilai koefisien sebesar 0,543 (positif) dengan nilai t-statistic sebesar 3,224 diatas nilai kritis 1,96 dan $p \_v a l u e=0,001<0,05$, berarti perhitungan memberikan gambaran bahwa peningkatan profitabilitas dibarengi oleh meningkatnya struktur modal. Sesui hipotesis (H3) yang diangkat maka hasil ini tidak dapat diterima. Hasil studi ini sejalan dengan temuan Nugroho (2014) yang menyatakan profitabilitas berpengaruh positif signifikan terhadap struktur modal pada Usaha Mikro Kecil dan Menengah (UMKM) kerajinan kuningan di Kabupaten Pati. Sejalan juga dengan hasil penelitian yang dilakukan oleh Chen and Chen (2011) menunjukkan bahwa profitabilitas dapat dianggap sebagai variabel penjelas dari struktur modal pada bursa efek Taiwan. Hasil studi ini tidak mendukung penelitian yang dilakukan oleh Dahlena (2017), Bhawa dan Rusmala Dewi S (2015) yang menemukan profitabilitas tidak berpengaruh terhadap struktur modal. Elim dan Yusfarita (2010), Septiono, Suhadak, and Darminto (2013) yang menyatakan profitabilitas mempunyai pengaruh negatif dan signifikan terhadap struktur modal.

Pengaruh profitabilitas terhadap nilai perusahaan

Hipotesis keempat; yang menyatakan antara

profitabilitas

terhadap

nilai perusahaan.Hasil analisis menemukan koefisien sebesar 0,494 (positif) dengan nilai t hitung 3,062 $(>1,96)$ atau nilai $p$-value sebesar $0,002(\mathrm{p}<0,05)$. Ini berarti profitabilitas berpengaruh signifikan positif terhadap nilai perusahaan sehingga hipotesis keempat dapat diterima. Hasil dari studi ini mendukung temuan yang dilakukan oleh Analisa (2011), Dj, Artini, and Suarjaya (2012) , Putra dan Wiagustini (2013) , Lubis, Sinaga, dan Sasongko (2017), Antoro dan Hermningsih (2017), Puspitaningtyas (2017) yang membuktikan bahwa profitabilitas berpengaruh signifikan positif terhadap nilai perusahaan. Berbeda dengan hasil riset yang didapat oleh Apriada dan Suardikha (2016) , Wahyudi, Chuzaimah, dan Sugiarti (2017) dimana profitabilitas memiliki pengaruh positif tidak signifikan terhadap nilai perusahaan.

\section{Pengaruh struktur modal terhadap nilai} perusahaan

Hipotesis kelima; yang menyatakan bahwa terdapat pengaruh signifikan positif antara struktur modal terhadap nilai perusahaan.Hasil analisis menemukan koefisien sebesar 0,365 (positif) dengan nilai t hitung 1,903 $(<1,96)$ atau nilai $p$-value sebesar $0,048(\mathrm{p}>0,05)$. Ini berarti struktur modal berpengaruh tidak signifikan positif terhadap nilai perusahaan sehingga hipotesis kelima tidak dapat diterima. Hasil studi ini sejalan dengan hasil yang didapat oleh Analisa (2011),Antoro dan Hermningsih (2017) yang mendapatkan ratio hutang berpengaruh tidak signifikan positif terhadap nilai perusahaan perbankan. Temuan Thaib and Dewantoro (2017), Ariyanti (2019) mendapatkan kebijakan hutang berpengaruh positif tidak signifikan terhadap nilai perusahaan. Hasil studi ini tidak sejalan dengan temuan yang dilakukan oleh Cheng dan Tzeng (2011), Mardiyati dan Ahmad (2012) , Gill and Obradovich (2017) menyatakan bahwa ratio hutang berpengaruh signifikan positif terhadap nilai perusahaan. Hasil riset Ferina, Tjandrakirana, and Ismail (2015) menemukan kebijakan utang tidak memiliki pengaruh yang signifikan terhadap nilai perusahaan. Bahkan Dewi and Wirajaya (2013) mendapatkan struktur modal berpengaruh negatif signifikan terhadap nilai perusahaan di Bursa Efek Indonesia periode 2009-2011

Pengaruh ukuran perusahaan terhadap nilai perusahaan melalui struktur modal sebagai variable mediasi bahwa terdapat nengaruh sionifikan positif Berdasarkan teknik analisis diatas hahwa_efek 
mediasi (intervening) akan di analisis dengan pendekatan uji sobel (Sobel Test). Sesuai dengan hasil pengolahan data didapat nilai koefisien untuk ukuran perusahaan ke struktur modal sebesar 0,165 dengan error sebesar 0,042 . Sedangkan nilai koefisien untuk struktur modal ke nilai perusahaan sebesar 0,642 dengan error sebesar -0,054, sehingga berdasarkan formulasi sobel test didapat nilai (Zsobel) sebesar $-3,7302$ dengan prob $0,000<0,05$. Berdasarkan perhitungan maka dapat dikatakan struktur modal belum mampu menjadi variable mediasi dalam mengintervensi pengaruh ukuran perusahaan terhadap nilai perusahaan.

\section{Pengaruh profitabilitas terhadap nilai perusahaan melalui struktur modal sebagai variable mediasi}

Sesuai dengan hasil pengolahan data didapat nilai koefisien untuk profitabilitas ke struktur modal sebesar 0,554 dengan error sebesar -0,022. Sedangkan nilai koefisien untuk struktur modal ke nilai perusahaan sebesar 0,642 dengan error sebesar -0,054, sehingga berdasarkan formulasi sobel test didapat nilai (Zsobel) sebesar 10,7509 dengan prob $0,000<0,05$. Berdasarkan perhitungan maka dapat dikatakan struktur modal mampu menjadi variable mediasi dalam mengintervensi pengaruh profitabilitas terhadap nilai perusahaan.

\section{SIMPULAN DAN SARAN \\ Simpulan}

Hipotesis pertama; yang menyatakan bahwa terdapat pengaruh signifikan positif antara ukuran perusahaan terhadap nilai perusahaan.Hasil analisis menemukan koefisien sebesar $-0,020$ (negatif) dengan nilai t hitung $0,111(<1,96)$ atau nilai $p$-value sebesar $0,911(\mathrm{p}>0,05)$. Ini berarti ukuran perusahaan berpengaruh negative tidak signifikan terhadap nilai perusahaan sehingga hipotesis pertama tidak dapat diterima.

Hipotesis kedua ; yang menyatakan ukuran perusahaan (size) berpengaruh positif signifikan terhadap struktur modal. Hasil analisis menemukan koefisien sebesar -0,101 (negatif) dengan nilai $t$ hitung $0,385(<1,96)$ atau nilai $p$ value sebesar $0,700(p>0,05)$. Ini berarti ukuran perusahaan berpengaruh negative tidak signifikan terhadap struktur modal sehingga hipotesis kedua tidak dapat diterima. Hipotesis ketiga ; yang menyatakan profitabilitas (profitability) berpengaruh $\mathrm{negat}$ if signifikan terhadap struktur modal. Hal ini ditunjukkan oleh nilai koefisien sebesar 0,543 (positif) dengan nilai tstatistic sebesar 3,224 diatas nilai kritis 1,96 dan p_value $=0,001$, berarti hipotesis (H3) tidak dapat diterima

Hipotesis keempat; yang menyatakan bahwa terdapat pengaruh signifikan positif antara profitabilitas terhadap nilai perusahaan.Hasil analisis menemukan koefisien sebesar 0,494 (positif) dengan nilai t hitung 3,062 $(>1,96)$ atau nilai $p$-value sebesar $0,002(\mathrm{p}<0,05)$. Ini berarti hipotesis keempat dapat diterima.

Hipotesis kelima; yang menyatakan bahwa terdapat pengaruh signifikan positif antara struktur modal terhadap nilai perusahaan.Hasil analisis menemukan koefisien sebesar 0,365 (positif) dengan nilai $t$ hitung $1,903(<1,96)$ atau nilai $p$-value sebesar $0,048(p>0,05)$. Ini berarti struktur modal berpengaruh tidak signifikan positif terhadap nilai perusahaan sehingga hipotesis kelima tidak dapat diterima.

Berdasarkan perhitungan dapat dikatakan struktur modal belum mampu menjadi variable mediasi dalam mengintervensi pengaruh ukuran perusahaan terhadap nilai perusahaan.Sedangkan pada sisi lain struktur modal mampu menjadi variable mediasi dalam mengintervensi pengaruh profitabilitas terhadap nilai perusahaan.

\section{Saran saran}

Bagi peneliti berikutbya diharapkan menambah jumlah variabel baik variabel yang sifatnya fundamental seperti kebijakan dividen, likuiditas, risiko bisnis,keputusan investasi,risiko bisnis, pertumbuhan perusahaan maupun variabel yang terkait dengan indikator ekonomi makro seperti suku bunga, nilai tukar,inflasi, dan kebijakan makro lainnya. Disamping itu penelitian kedepan diharapkan memperluas populasi penelitian dengan memasukkan sektor manufaktur yang lain yang terdatar di BEI.
DAFTAR PUSTAKA

Adiputra, I Gede. 2016. "The Effect of Internal and External Factors on the Value of a Finn Through Its Investment
Opportunities on the Stock Exchange of the Southeast Asian Countries" 10 (4): 370-376. 
Adrianto, dan Wibowo. 2007. "Pengujian Teori Pecking Order Pada Perusahaan- Perusahaan Non Keuangan LQ45 Periode 2001-2005." Manajemen Usahawan Indonesia XXXVI (12): 43-53.

Agha. 2015. "Determinants of Capital Structuring Of Firms of Cement Sector in Pakistan." European Scientific Journal May 2015 Edition vol.11, No.13 ISSN: 1857 7881 (Print) E - ISSN 1857- 74318 (1): 77-92.

Analisa, Yangs. 2011. "Pengaruh Ukuran Perusahaan, Leverage, Profitabilitas Dan Kebijakan Dividen Terhadap Nilai Perusahaan." Skripsi" Fakultas Ekonomi Dsn Bisnid Universitas Diponegoro. Universitas Diponegoro Semarang.

Ananta, Gede Eka Ferry, I Made Sadha Suardikha, and Ni Made Dwi Ratnadi. 2014. "Pengaruh Kepemilikan Manajerial, Keputusan Investasi, Keputusan Pendanaan, Dan Kebijakan Dividen Pada Nilai Perusahaan Di Bursa Efek Indonesia." E-Jurnal Ekonomi Dan Bisnis Universitas Udayana 9 (3): 494-505.

Anjarwati, Kenti, Mochammad Chabachib, and Irene Rini Demi. 2015. "Pengaruh Profitabilitas, Size, Dan Likuiditas Terhadap Nilai Perusahaan Manufaktur Di Indonesia Dengan Struktur Modal Sebagai Variabel Intervening." Diponegoro Journal of Finance 6 (2): 120.

Antoro, Dwi Antoro, dan Sri Hermningsih. 2017. "Kebijakan Dividen Dan BI Rate Sebagai Pemoderasi Likuiditas,Profitabilitas, Dan Leverage Terhadap Nilai Perusahaan Perankan Yang Terdaftar Di BEI 20112017." Upajiwa Dewantara 2 (1): 58-75.

Apriada, Kadek, dan Sadha Made Suardikha. 2016. "Pengaruh Struktur Kepemilikan Saham, Struktur Modal Dan Profitabilitas Pada Nilai Perusahaan." E-Jurnal Ekonomi Dan Bisnis Bisnis Universitas Udayana 5 (2): 201-218.

Ariyanti, Rizka. 2019. "Pengaruh Tangible Asset, ROE, Firm Size, Liquidty Terhadap Price Book Value Dengan Struktur Modal Sebagai Variabel Intervening Pada Perusahaan Perbankan." BALANCE: Economic, Business, Management and Accounting Journal 16 (1): 1-11. https://doi.org/10.30651/blc.v16i1.2450.

Astakoni, I Made Purba, dan Ni Putu Nursiani. 2020. "Efek Intervening Struktur Modal Pada Pengaruh Ukuran Perusahaan Terhadap Profitabilitas.” Krisna Kumpulan Riset Akuntansi 11 (2): 137-47.

Astakoni, I Made Purba, dan Ni Made Satya Utami. 2019. "Determinan Kebijakan Dividen Perusahaan Manufaktur." Jurnal Riset Akuntansi Juara 9 (2): 8191.

Astakoni, I Made Purba, dan I Wayan Wardita. 2020. "Keputusan Investasi, Leverage, Profitabilitas, Dan Ukuran Perusahaan Sebagai Faktor Penentu Nilai Perusahaan Manufaktur." Wacana Ekonomi (Jurnal Ekonomi,Bisnis Dan Akuntansi) 19 (1): 10-23.

Astakoni, Purba I Made, dan Ni Putu Nursiani. 2019. "Dividen Policy, Company Size And Growth As A Determining Factor Of Debt Policy" 3 (5): 168-77.

Awan, Abdul Ghafoor, Muhammad Usman Lodhi Lodhi, and Dilshad Hussain. 2018. "Determinants of Firm Value: A Case Study of Chamical Industries." Global Journal of Management, Social Sciences and Humanities 4 (1): 46-61.

Ayako, Aloys, and Fidelis Wamalwa. 2015. "Determinants of Firm Value in Kenya: Case of Commercial Banks
Listed at the Nairobi Securities Exchange." Applied Finance and Accounting 1 (2): 129-142. https://doi.org/10.11114/afa.v1i2.934.

Bhawa, Ida Bagus Made Dwija, and Made Rusmala Dewi S. 2015. "Pengaruh Ukuran Perusahaan, Likuiditas, Profitabilitas, Dan Risiko Bisnis Terhadap Struktur Modal Perusahaan Farmasi." E-Jurnal Manajemen 4 (7): 1949-1966. https://doi.org/ISSN:2302-8912.

Brigham, EF., and J. Houston. 2006. Dasar- Dasar Manajemen Keuangan. Edisi X. Jakarta: Salemba Empat.

Brigham, Eugene F., and Joel F. Houston. 2011. Dasar-Dasar Manajemen. Keuangan. Jakarta: Salemba Empat.

Budhiasa, Sudjana. 2016. Analisis Statistik Multivariate Dengan Aplikasi SEM PLS SmartPLS 3.2.6. Edited by Jiwa Atmaja. Edisi Pert. Denpasar: Udayana University Press.

Chen, Shun-yu, and Li-ju Chen. 2011. "Capital Structure Determinants : An Empirical Study in Taiwan" 5 (27): 10974-10983. https://doi.org/10.5897/AJBM10.1334.

Cheng, Ming-chang, and Zuwei-Ching Tzeng. 2011. "The Effect of Leverage on Firm Value and How the Firm Financial Quality Influence on This Effect." World Journal of Management 3 (2): 30-53.

Dahlena, Murni. 2017. "Pengaruh Likuiditas Risiko Bisnis Dan Profitabilitas Terhadap Struktur Modal Pada Perusahaan Textile Dan Garment Yang Terdaftar Di BEI." Jurnal Riset Akuntansi Dan Bisnis, ISSN;1693175917 (2).

Dewi, Ayu Sri Mahatma, and Ary Wirajaya. 2013. "Pengaruh Struktur Modal, Profitabilitas Dan Ukuran Perusahaan Pada Nilai Perusahaan.” E-Jurnal Akuntansi 4 (2): 358372.

Dj, Alfredo Mahendra, Luh Gede Sri Artini, and A.A Gede Suarjaya. 2012. "Pengaruh Kinerja Keuangan Terhadap Nilai Perusahaan Dengan Kebijakan Dividen Sebagai Variabel Pemoderasi." Jurnal Manajemen, Strategi Bisnis, Dan Kewirausahaan 6 (2): 130-138.

Elim, and Yusfarita. 2010. "Pengaruh Struktur Aktiva, Tingkat Pertumbuhan Penjualan, Dan Return On Asset Terhadap Struktur Modal Pada Perusahaan Manufaktur Di Bursa Efek Jakarta." Jurnal Bisnis Dan Ekonomi 1 (1): 88103.

Fajar, Aulia, Amir Hasan, and Gusnardi. 2018. "Analisis Pengaruh Profitabilitas, Ukuran Perusahaan Dan Leverage Operasi Terhadap Nilai Perusahaan Dengan Struktur Modal Sebagai Variabel Intervening (Studi Kasus Pada Perusahaan Subsektor Perkebunan Yang Terdaftar Di Bursa Efek Indonesia Tahun 2012-2016)." Jurnal Tepak Manajemen Bisnis 10 (4): 662-679.

Ferdinand, Augusty. 2014. Structural Equation Modeling. 5thed. semarang: Badan Penerbit Universitas Diponegoro Semarang.

Ferina, Ika Sasti, Hj.Rina Tjandrakirana, and Ilham Ismail. 2015. "Pengaruh Kebijakan Dividen, Kebijakan Hutang, Dan Profitabilitas Terhadap Nilai Perusahaan (Studi Pada Perusahaan Pertambangan Yang Terdaftar Di BEI Periode 2009-2013)." Jurnal Akuntanika 2 (1): 52-66. https://doi.org/10.1017/CBO9781107415324.004.

Ghozali, Imam. 2011. Aplikasi Analisis Multivariate Dengan Program SPSS 19. Edited by Prayogo P.Harto. V. Semarang: Badan Penerbi Univ Diponogoro.

Gill, Amarjit, and John Obradovich. 2017. "The Impact of Corporate Governance and Financial Leverage on Value 
of Firms Listed on Amman Stock Exchange." Jordan Journal of Business Administration 12 (4): 899-917. https://doi.org/10.12816/0034973.

Hasibuan, Veronica, Moch Dzulkirom AR, and N G Wi Endang NP. 2016. "Pengaruh Leverage Dan Profitabilitas Terhadap Nilai Perusahaan (Studi Pada Perusahaan Property Dan Real Estate Yang Terdaftar Di Bursa Efek Indonesia Periode Tahun 2012-2015)." Jurnal Administrasi Bisnis (JAB) 39 (1): 1-13. http://digilib.unpkediri.ac.id/mahasiswa/file_artikel/201 6/12.1.02.01.0026.pdf.

Hermuningsih, Sri. 2012. "Pengaruh Profitabilitas, Size Terhadap Nilai Perusahaan Dengan Sruktur Modal Sebagai Variabel Intervening." Jurnal Siasat Bisnis 16 (2): 232-42. https://doi.org/10.20885/jsb.vol16.iss2.art8.

Horne, James C.Van,dan WachoWicz JR John M. 2012. Prinsip Prinsip Manajemen Keuangan. Edisi Ke12. Jakarta: Salemba Empat.

Husnan, Suad, dan Enny Pudjiastuti. 2010. Dasar- Dasar Manajemen Keuangan, Jilid I. Yogyakarta: UPP - AMP YKPN.

Ibrahim, Mahmoud. 2017. "Capital Structure and Firm Value in Nigerian Listed Manufacturing Companies: An Empirical Investigation Using Tobin's Q Model." International Journal of Innovative Research in Social Sciences \& Strategic Management Techniques 4 (2): $112-125$.

Kartini, dan Arianto Tulus. 2008. "Struktur Kepemilikan, Profitabilitas, Pertumbuhan Aktiva Dan Ukuran Perusahaan Terhadap Struktur Modal Pada Perusahaan Manufaktur." Jurnal Keuangan Dan Perbankan 12 (1): Hal 11-21.

Keown, Arthur J, John D Maritin, dan F.Sccott David. 2010. Manajemen Keuangan Prinsip Dan Penerapan (Terjemahan Oleh Marcus Prihminto Widodo). Jakarta: Indeks.

Kosimpang, Anung Dian. 2017. "Pengaruh Profitabilitas, Ukuran Perusahaan Terhadap Nilai Perusahaan Dengan Variabel Struktur Modal Sebagai Variabel Intrvening Pada Prusahaan Pertambangan Yang Terdaftar Di BEI Periode Tahun 2012-2016." Semarang.

Kurniawati, Herni. 2016. "Pengaruh Board Size, Leverage, Dan Kualitas Audit Terhadap Nilai Perusahaan." Jurnal Keuangan Dan Perbankan 12 (2): 110-127.

Kusuma, Ginanjar Indra Suhadak, dan Zainul Arifin. 2012. "Analisis Pengaruh Profitabilitas (Profitability) Dan Tingkat Pertumbuhan (Growth) Terhadap Struktur Modal Dan Nilai Perusahaan (Studi Pada Perusahaan Real Estate and Property Yang Terdaftar Di Bursa Efek Indonesia (BEI) Periode 2007-2011).”Skripsi, Univ Merdeka, Malang.

Latan, Hengky, and Imam Ghozali. 2012. Partial Least Squares Konsep Teknik Dan Aplikasi SmartPLS 2.0 Untuk Penelitian Empiris. Edited by Harto Prayogo P. Semarang: Badan Penerbit Univ Diponogoro.

Lubis, Ignatius Leonardus, Bonar M Sinaga, and Hendro Sasongko. 2017. "Pengaruh Profitabilitas, Sruktur Modal, Dan Likuiditas Terhadap Nilai Perusahaan." Jurnal Aplikasi Bisnis Dan Manajemen 3 (3): 458-465. https://doi.org/10.17358/jabm.3.3.458.

Mai, Muhammad Umar. 2006. "Analisis Variabel-Variabel Yang Mempengaruhi Struktur Modal Pada PerusahaanPerusahaan LQ-45 Di Bursa Efek Jakarta.” Ekonomika, 228-245.
Mardiyati, Umi, and Gatot Nazir Ahmad. 2012. "Pengaruh Kebijakan Dividen, Kebijakan Hutang Dan Profitabilitas Terhadap Nilai Perusahaan Manufaktur Yang Terdaftar Di Bursa Efek Indonesia (BEI) Periode 2005-2010." Jurnal Riset Manajemen Sains Indonesia (JRMSI) Vol 3 (Nomor 1): Hal 1-17.

Martini, Ni Nyoman G., Moeljadi, Djumahir, dan Atim Djazuli. 2014. "Factors Affecting Firms Value of Indonesia Public Manufacturing Firms." International Journal of Business and Management Invention 3 (2): 35-44.

Mas'ud, Masdar. 2008. "Analisis Faktor-Faktor Yang Mempengaruhi Struktur Modal Dan Hubungannya Terhadap Nilai Perusahaan." Manajemen Dan Bisnis 7 (7): 69-83.

Mindra, Sukma, and Teguh Erawati. 2014. "Pengaruh Earning Per Share (EPS), Ukuran Perusahaan, Profitabilitas, Dan Leverage Terhadap Nilai Perusahaan.” Jurnal Akuntasi Vol 2 (No 2): 6-16

Moeldjadi. 2006. Manajemen Keuangan: Pendekatan Kuantitatif Dan Kualitatif. Jilid 1. Malang: Bayumedia Publishing.

Moeljadi. 2014. "Factors Affecting Firm Value." South East Asia Journal of Contemporary Business, Economics and Law 5 (2): 6-15.

Murhadi, Werner R. 2013. Analisis Laporan Keuangan Proyeksi Dan Evaluasi Saham. Jakarta: Salemba Empat.

Naceur, Samy Ben., and Mohamed. Goaied. 2002. "The Relationship Between Dividend Policy, Financial Structure, Profitability And Firm Value." Applied Financial Economics. 12: 843-849.

Novari, Putu Mikhy, and Putu Vivi Lestari. 2016. "Pengaruh Ukuran Perusahaan, Leverage, Dan Profitabilitas Terhadap Nilai Perusahaan Pada Sektor Properti Dan Real Estate.” E-Jurnal Manajemen Unud 5 (9): 56715694.

Nugroho, Nur Cahyo. 2014. “Analisis Pengaruh Profitabilitas, Pertumbuhan Penjualan, Ukuran Perusahaan, Dan Umur Perusahaan Terhadap Struktur Modal Usaha Mikro Kecil Dan Menengah Kerajinan Kuningan Di Kabupaten Pati." Management Analysis Journal 3 (2): 1-10. https://doi.org/10.15294/maj.v3i2.3951.

Nurminda, Aniela. 2017. "Pengaruh Profitabilitas, Leverage, Dan Ukuran Perusahaan Terhadap Nilai Perusahaan ( Studi Pada Perusahaan Manufaktur Sub Sektor Barang Dan Konsumsi Yang Terdaftar Di Bursa Efek Indonesia Periode 2012-2015 )." E-Proceeding of Management 4 (1): 542-549.

Ogolmagai, Natalia. 2011. "Leverage Pengaruhnya Terhadap Nilai Perusahaan Pada Industri Manufaktur Yang Go Public Di Indonesia.” Jurnal EMBA 1 (3): 81-89.

Prastuti, Rai Ni Kadek, and Merta I Gede Sudiartha. 2016. "Pengaruh Struktur Modal Kebijakan Dividen Dan Ukuran Perusahaan Terhadap Nilai Perusahaan Pada Perusahaan Manufaktur.” E-Jurnal Manajemen Unud 5 (3): 1572-1598.

Pratama, Gusti Bagus Angga, and Gusti Bagus Wiksuana. 2016. "Pengaruh Ukuran Perusahaan Dan Leverage Terhadap Nilai Perusahaan Dengan Profitabilitas Sebagai Variabel Mediasi." E-Jurnal Manajemen Unud 5 (2): 1338-1367.

Pratiwi, Ni Putu Diah, and Made Mertha. 2017. "Pengaruh Kebijakan Hutang Dan Profitabilitas Pada Nilai Perusahaan Dengan Kebijakan Dividen Sebagai 
Variabel Pemoderasi." E-Jurnal Akuntansi Universitas $\begin{array}{llll}\text { Udayana } & 20 & \text { (2): } & 1446-1475\end{array}$ https://doi.org/10.1038/srep44329.

Puspitaningtyas, Zarah. 2017. "Efek Moderasi Kebijakan Dividen Dalam Pengaruh Profitabilitas Terhadap Nilai Perusahaan Manufaktur." Jurnal Akuntansi, Ekonomi Dan Manajemen Bisnis 5 (2): 173-180. https://doi.org/10.30871/jaemb.v5i2.538.

Putra, Y Yudha Dharma, and Ni Luh Putu Wiagustini. 2013. "Pengaruh Likuiditas Dan Leverage Terhadap Profitabilitas Dan Nilai Perusahaan Pada Perusahaan Perbankan Di BEI.” Jurnal Wawasan Manajemen 1 (2): 215-232.

Rahmawati, Siti Hamda. 2015. "Analisis Faktor Faktor Yang Mempengaruhi Nilai Perusahaan (Studi Empiris Pada Perusahaan Perusahaan Yang Terdaftar Di BEI Tahun 2010-2012)." Jurnal Fekon 2 (1): 1-15.

Rajan, Raghuram G., and Luigi Zingales. 1995. "What Do We Know about Capital Structure? Some Evidence from International Data." The Journal of Finance 50 (5): 1421-1460. 6261.1995.tb05184.x.

Riyanto, Bambang. 2010. Dasar Dasar Pembelanjaan Perusahaan. Yogyakarta: BPFE.

Rudangga, I Gusti Ngurah Gede, and Gede Merta Sudiarta. 2013. "Pengaruh Ukuran Perusahaan, Leverage Dan Profitabilitas Terhadap Nilai Perusahaan." E-Jurnal Manajemen Unud 5 (7): 4394-4422.

Sabrina, Sasya, Armanto Witjaksono, and Lusianah. 2018. "The Most Influential Factors Toward Firm Value ( Case Study in Indonesia )." https://www.researchgate.net/profile/Armanto_Witjakso no? enrichId= rgreq2f4e238168351e9calbe59bee6699c3e-April 15,2019, no. March: 0-12.

Sartono, Agus. 2010. Manajemen Keuangan Teori Dan Aplikasi. Edited by Ali Akbar Yulianto. Edisi 11. Yogyakarta: BPFE Yogyakarta.

Schoubben, F., And, and C Van Hulle. 2004. "The Determinant of Leverage: Difference between Quoted and Non Quoted Firms." Tijdschrift Voor Economie En Management XLIX (4): 44-54.

Seftianne, and Handayani Ratih. 2011. "Faktor Faktor Yang Mempengaruhi Struktur Modal Pada Perusahaan Publik Sektor Manufaktur." Jurnal Bisnis Dan Akuntansi Vol 13 (No 1): Hal 39-56.

Septiono, Rizqy Wahyu, Suhadak, and Darminto. 2013. “Analisis Faktor Mikro Terhadap Struktur Modal Dan
Nilai Perusahaan.” Jurnal Administrasi Bisnis 2 (1): $138-151$.

Siallagan, Hamonangan, and Mas'ud MachffoedzZ. 2006. "Mekanisme Corporate Governance, Kualitas Laba Dan Nilai Perusahaan." Simposium Nasional Akuntansi 9 Padang 13 (61): 23-26.

Sitepu, Novi Rehulina, and C.Handoyo Wibisono. 2013. "Pengaruh Kebijakan Dividen, Kebijakan Leverage Dan Profitabilitas Terhadap Nilai Perusahaan." Http://ejournal.uajy.ac.id/8708/1/JURNALEM19344.pdf, Diakses 17 April 2019, 1-14.

Sugiyono. 2007. Metode Penelitian Bisnis (Pendekatan Kuantitatif, Kualitatif Dan R\&D). 2nded. Bandung: Alfabeta. website:www.cvalfabeta.com.

Suliyanto. 2011. Ekonometrika Terapan Teori \& Apalikasi Dengan SPSS. Edited by Fl. Sigit Suyantoro. Ed.I. Yogyakarta: CV.ANDI OFSET.

Syamsuddin, Lukman. 2004. Manajemen Keuangan Perusahaan. Jakarta: PT Raja Grafindo Persada.

Thaib, Ilham, and Acong Dewantoro. 2017. "Pengaruh Profitabilitas Dan Likuiditas Terhadap Nilai Perusahaan Dengan Struktur Modal Sebagai Variabel Intervening." Jurnal Riset Perbankan Manajemen Dan Akuntansi 1 (1): 25-44.

Titman, Sheridan. 1984. "The Effect of Capital Structure on a Firm's Liquidation Decision." Journal of Financial Economics $13 \quad$ (1): 137-151. https://doi.org/10.1016/0304-405X(84)90035-7.

Vaeza, Neisya Dieta, and Dini Wahjoe Hapsari. 2015. "Pengaruh Ukuran Perusahaan, Profitabilitas, Leverage Dan Kebijakan Dividen Terhadap Nilai Perusahaan Pada Perusahaan Sektor Manufaktur Yang Terdaftar Di Bura Efek Indonesia Periode 2010-2013.” E-Proceeding of Management 2 (3): 3310-3317. https://doi.org/10.1080/1600910X.2005.9672914.

Wahyudi, Henri Dwi, Chuzaimah Chuzaimah, and Dani Sugiarti. 2017. "Pengaruh Ukuran Perusahaan, Profitabilitas, Kebijakan Dividen Dan Keputusan Investasi Terhadap Nilai Perusahaan (Studi Penggunaan Indeks LQ-45 Periode 2010 -2014)." Benefit: Jurnal Manajemen Dan Bisnis 1 (2): 156-167. https://doi.org/10.23917/benefit.v1i2.3259.

Wardita, I Wayan, and I Made Purba Astakoni. 2018. "Profitabilitas, Pertumbuhan Perusahaan Dan Ukuran Perusahaan Sebagai Determinan Struktur Modal." KRISNA: Kumpulan Riset Akuntansi 9 (2): 20-29 https://doi.org/10.22225/kr.9.2.468.20-32. 